\title{
Periprostetik enfeksiyonlar: mikrobiyoloji, antibiyotik uygulamaları
}

\author{
Periprosthetic infections: microbiology, antibiotic usage
}

\author{
Halit Özsüt
}

İstanbul Üniversitesi İstanbul Tıp Fakültesi, Enfeksiyon Hastalıkları ve Klinik Mikrobiyoloji Anabilim Dalı, İstanbul

\begin{abstract}
Periprostetik eklem enfeksiyonu, hastalar için muazzam bir yüktür. Artroplastilerinde enfeksiyon görülme oranı düşüktür, ancak uygun yönetim fonksiyonların geri kazanılmasında ve aşırı morbiditenin önlenmesinde kritik öneme sahiptir. Bu derlemede, periprostetik eklem enfeksiyonlarının mikrobiyolojisi ve antibiyotik uygulamaları tartışılmaktadır.
\end{abstract}

Anahtar sözcükler: protez; enfeksiyon; antibiyotik
Periprosthetic joint infection is a tremendous burden for patients. While a small minority of joint arthroplasties will become infected, appropriate management is critical to preserve or restore adequate function and prevent excess morbidity. In this review, we discuss the microbiology and the antibiotic applications for periprosthetic joint infections.

Key words: prosthesis, infection, antibiotic
T otal protez enfeksiyonları, tedavisi güç ve süresi oldukça uzun, ekip çalışması, bilgi birikimi ve deneyim gerektiren enfeksiyonlardır. ${ }^{[1-10]}$ Kesin enfeksiyon oranlarını elde etmek güç olup, bu oranlar, yerleştirilen ekleme ve operasyondan sonra geçirilen sürenin uzunluğuna bağlı olarak değişmekle birlikte, protez eklem yerleştirme işlemlerinde, son zamanlarda, en iyi koşullarda \%1-2'ye düşmüştür. ${ }^{[11]}$ Bu nedenle, izlemleri ve yönetimleri kolay değil, hatta oldukça zordur. ${ }^{[11]}$ Hastanın sabır göstermesine şiddetle gereksinim vardır.

Total protez cerrahisi sonrası ortaya çıkan enfeksiyonlarda en sık etken patojenler, bakterilerdir. Etkenlerin \%50'sinden fazlası stafilokoklardır (\%30-43 koagülaz-negatif stafilokoklar, \%12-23 Staphylococcus aureus). ${ }^{[12]}$ Daha sonra, sıklık sırasına göre, \%9-10 streptokoklar, \%3-6 Gram-negatif çomaklar, \%3-7 enterokoklar gelir. Revizyon öncesi, özellikle düşükdereceli (low-grade) enfeksiyonlarda, etkenleri saptamak için, en az iki hafta süreyle antibiyotikler kesilmeli ve operasyon sırasında kültür için doku örnekleri alındıktan sonra, profilaksi/tedavi amaçlı antibiyoterapi başlanılmalıdır. ${ }^{[13]}$ Protezin çıkarıldığı durumlarda, implantın tüm komponentlerinin zenginleştirilmiş sıvı besiyerlerinde kültürü yapılmalıdır. ${ }^{14]}$ Bununla birlikte, sıvı besiyerlerinde kontaminasyon riskinin oldukça yüksek olabileceği akılda tutulmalıdır. Son zamanlarda, üreme oranlarını arttırmak için sonikasyon yöntemini kullanan üniteler vardır. ${ }^{[15]}$ Üretilen bakterinin gerçek etken olup olmadığına, çok dikkatli bir bakış açısıyla karar verilmelidir.

Staphylococcus aureus gibi virulansı yüksek bir bakterinin üretilmesi büyük bir olasılıkla enfeksiyon varlığını düşündürürken, virulansı düşük normal deri flora üyelerinin (koagülaz-negatif stafilokoklar, Propionibacterium acnes vb.) üretilmesi, kontaminasyon da olabileceğini akla getirilmelidir. Staphylococcus aureus, hastane enfeksiyonlarında olduğu gibi, toplum kökenli total protez enfeksiyonlarında da en önemli patojenlerden birisidir; çoğunlukla erken enfeksiyonlardan sorumludur. Staphylococcus epidermidis ve diğer koagülaz-negatif stafilokoklar, klinik örneklerde kültür kontaminantı

- İletişim adresi: Prof. Dr. Halit Özsüt, İstanbul Üniversitesi İstanbul Tıp Fakültesi, Enfeksiyon Hastalıkları ve Klinik Mikrobiyoloji Anabilim Dalı, İstanbul Tel: 0532 - 2412932 e-posta: halitozsut@superonline.com

- Geliștarihi: 1 Mart 2016 Kabul tarihi: 1 Mart 2016 
olarak bulunabilir, ancak bunlar gerçek patojen de olabilir. Bu bakteriler, kalıc yabancı cisimleri etkilemekte, biyofilm oluşturmakta ve eklem protezlerin kullanımı arttıkça daha sık etken olarak ortaya çıkmaktadır. Koagülaz-negatif stafilokokların neden olduğu protez enfeksiyonları, sinsi seyirli olmaları ile karakterizedir. Yukarıda belirtilen etkenler dışında, normal kültürlerde güç üreyen, önceleri nütrisyonel varyant streptokok olarak adlandırılan, Abiotrophia defectiva veya Granulicatella adiacens'in ve küçük-koloni varyant stafilokokların da etken olabileceği bildirilmektedir. Küçük-koloni varyant stafilokokların, özellikle persistans gösteren ve nüks eden olgularda izole edildiği bildirilmiştir. Literatürde Streptococcus pneumoniae, B grubu streptokoklar, Listeria monocytogenes, Haemophilus parainfluenzae, Yersinia enterocolitica, Pasteurella multocida, Clostridium difficile, Campylobacter fetus, Campylobacter lari, Oerskovia xanthineolytica, Helcococcus pyogenica, Mycobacterium tuberculosis, Mycobacterium fortuitum, Brucella spp, Tropheryma whippelii, Candida spp ve Actinomyces israelii'nin seyrek de olsa etken olabildiklerine dair yayınlar vardır.

Olası etken patojenlerin birden fazla örnekte üremesi, kültür pozitifliğinin kısa sürede gerçekleşmesi (erken üreme), Gram preparatında etken görülmesi, histopatolojik olarak akut inflamasyonun kanıtlanması, genellikle etken olduklarını destekler.

Sinoviyal sıvının ve/veya periprostetik dokunun Gram yöntemiyle boyanmasının özgüllüğü yüksek (>\%97), fakat duyarlılığı oldukça düşüktür (<\%26).

Yüzeyel sürüntü ve/veya sinus ağzı kültürlerinin, kolonizasyon nedeniyle değerleri yoktur ve bu nedenle yapılmamaları gerekir. Aspirasyonla elde edilen eklem sıvısı örneğinde \%45-100 patojen üretilebilir. Periprostetik doku kültürleri, etken patojenlerin sıklıkla izole edilmesini sağlar ve giderek artan sıklıkta kullanılmaktadır; özellikle, eklem aspirasyonundan kaçınılan, cerrahi sonrası erken enfeksiyonlarda önemli bir işlev görür. ${ }^{[16]}$ $\mathrm{Bu}$ kültürlerin duyarlılığı, enfeksiyon tanımlamasına bağlı olarak \%65-94 arasında değişmektedir. Ameliyat sırasında kültür örneği alınırken, en az üç adet olmasına özen gösterilmelidir; hatta en az 5-6 örnek alınmasını telkin eden çalışma sonuçları da vardır. ${ }^{[17]}$

Son yıllarda, total protez enfeksiyonlarının tanısında immünofloresan mikroskopi ve PCR (polimeraz zincir reaksiyonu) gibi moleküler yöntemlerin kullanılmasıyla ilgili araştırmalar yapılmaktadır. ${ }^{[18,19]}$ Yakın zamanda, Amerikan Enfeksiyon Derneği'nin yıllık toplantısında bildirilen bir çalışmada, PCR'nin kültüre bir üstünlüğü olmadığı bildirilmiştir.

Antibiyotik direnci, total protez enfeksiyonu etkenlerinde önemli bir sorundur. Özellikle son iki dekad içinde, hastane suşlarında ciddi bir direnç artışı söz konusudur. Hem hastane hem de toplum kökenli total protez enfeksiyonlarında, metisiline ve diğer antibiyotiklere dirençli Staphylococcus aureus (MRSA), giderek artan sıklıkta izole edilmekte ve bu, hastanın MRSA ile daha önceden kolonizasyonu veya enfeksiyon riskini arttırmaktadır. ${ }^{[20]}$

Protez eklem enfeksiyonunun kesin tanısında seçilecek yöntem, eklem sıvısının aspirasyonu ve cerrahi sırasında alınan doku örneklerinin kültürü, histopatolojik ve klinik mikrobiyolojik tetkiklerdir. Yapılan bir çalışmada, enfekte eden mikroorganizmaları tespit etmek amacıyla yapılan ince iğne aspirasyonu, cerrahi işlem sırasında alman biyopsi kültürleri ile karşılaştırılmış, duyarlılığı \%87 ve özgüllüğü \%95 bulunmuştur.

Yeni antibiyotik tedavisi verilmeden, mutlaka kültürler alınmalıdır. Mikrobiyolojik olarak tanı konması kritik önem taşıdığından, akut olmayan olguların çoğunda, aspirasyon yapılarak ve/veya ameliyat esnasında kültür alınıncaya kadar, antimikrobik tedavi verilmemelidir. Eğer antimikrobik tedaviye başlanırsa, mümkünse yalancı-negatif sonuçlardan kaçınmak için, herhangi bir tanısal işlemden 14 gün önce tedavi kesilmelidir. Aerop ve anaerop kültür rutin olarak yapılmalıdır. Tanısal eklem aspirasyonu sırasında, kültür için mümkün olduğu kadar fazla sıvı alınmalıdır. Protez debridmanı yapılırken veya protez çıkarılırken, cerrah, kültür ve histopatoloji için çok sayıda örnek almalıdır. Ameliyat sırasında alınan kültürler, kemik-çimento yüzleri arasındaki ve mümkünse pürulans olan dokuları içermelidir. Kronik enfeksiyonlarda, mikobakteri ve mantar kültürleri alınması da tavsiye edilir. İzole edilen bakterilerin hepsi için duyarlılık çalışmaları özenle yapılmalıdır.

Başarısız bir protez için yapılan revizyon artroplasti sırasında, alınan tek bir tarama kültür sonucunun öngörü değeri bilinmemektedir; böyle bir sonuç, klinik durumla birlikte dikkatle değerlendirilmelidir.

Sinus ağızlarından gelen akıntıdan alınan kültürler, etiyolojik mikroorganizmaları güvenilir bir şekilde saptayamaz.

Septik hastalarda kan kültürleri rutin olarak alınmalıdır (örneğin, 30-60 dakika arayla iki veya üç örnek alınır).

Staphylococcus aureus, tedavisi en güç ortopedik enfeksiyon etkenlerinden biridir. Staphylococcus aureus osteoblastlar tarafindan alındığı zaman, dorman bir şekilde ve uzun bir süre, fenotipik olarak değişik safhada yaşamını sürdürebilir. Bu değişik safha, Staphylococcus aureus'a antibiyotiklerin etkisinin daha az olmasına neden olmaktadır; bu durum, kısa süreli antibiyoterapilerin yüksek rölaps oranını ve 
uzun inkübasyon süresini açıklamaya yardım eder. Stafilokokların yarattığı diğer bir durum, antibiyotik direnci nedeniyle, bu bakterilerin oluşturduğu enfeksiyonların tedavilerinde ve cerrahi profilakside karşılaşılan güçlüklerdir. MRSA, ilk kez yaklaşık beş dekad önce tanımlanmış olup, evrimsel değişiklikleri ve epidemiyolojik olarak yayılımı devam etmektedir. MRSA, hastane enfeksiyon etkeni olarak belirlenmesinin yanı sıra, artık toplumda da ortaya çıkmaktadır. Bu durum, toplum kökenli enfeksiyonların tedavisinde seçilecek antibiyotiklerde önemli bir değişikliğe neden olduğu gibi, yeni antibiyotiklerin geliştirilmesine de yol açmıştır. Genellikle hastane kökenli MRSA suşlarında çoğul antibiyotik direnci söz konusu iken, toplum kökenli MRSA suşlarında direnç daha sınırlıdır. Koagülaz-negatif stafilokok türlerinin de çoğu metisiline dirençlidir. MRSA enfeksiyonlarının tedavisi oldukça güçtür, çünkü sadece kısıtlı sayıdaki antibiyotik MRSA'ya karşı etkilidir. Ayrıca, enfeksiyon antibiyotik penetrasyonunun azaldığı anatomik alanlarda (örneğin kemikte) olduğundan, tedavi yine güçleşmektedir. MRSA prevalansının artışına bağlı olarak, tedavide glikopeptidler (vankomisin ve teikoplanin) çok daha sık olarak kullanılmaktadır. ${ }^{[21,22]}$ Ancak, glikopeptidlerin artan kullanımı, son yıllarda, vankomisin ve teikoplanine orta duyarlı (VISA) veya tam dirençli (VRSA) stafilokok suşlarının ortaya çıkışı ile sonuçlanmıştır. Glikopeptidlere duyarlılığı azalmış Staphylococcus aureus tiplerinin her birinde, direnç mekanizması farklıdır. Bu enfeksiyonlar, glikopeptid tedavisinin klinik başarısızlığı ile birliktedir. Staphylococcus aureus gibi koagülaz-negatif stafilokoklarda da glikopeptid direnci bildirilmektedir. Biyofilm nedeniyle, tedaviye rifampisin eklenmesi önerilmektedir. ${ }^{[5,22]}$

Total protez enfeksiyonları, cerrahi ve uzun süreli antibiyoterapi gerektiren, tedavisi zahmetli enfeksiyonlardır. Bu nedenle, tedavi öncesi mutlaka etken patojeninin izole edilmesine ve antibiyogram yapılmasına özen gösterilmeli; tedavi, istisnai olgular dışında, mutlaka antibiyogram eşliğinde, rasyonel olarak yapılmalıdır. Uzun süreli antibiyoterapilerin istenmeyen etkileri de, böylece minimum oranlarda tutulabilir.

Ortopedik protez takılan her hasta, enfeksiyon gelişimi açısından eşit risk altında değildir. Cerrahi öncesi değerlendirme bu açıdan büyük önem taşımaktadır. Genel enfeksiyon risk faktörleri; ileri yaş, geçirilmiş artroplasti ve eşlik eden veya altta yatan hastalıklardır. ${ }^{[23]}$

Enfeksiyon gelişim riskini arttıran sistemik konak (medikal/immün sistem) ve lokal ekstremite/yara durumu faktörleri söz konusudur. ${ }^{[24]}$ Sistemik konak faktörleri;
- ileri yaş ( $\geq 80$ yaş),

- sistemik inflamatuvar hastalıklar (artropati ile seyreden romatoid artrit, SLE, vb.),

- immünosupresyon (ilaca bağlı: kortikosteroidler, metotreksat, azatioprin, siklosporin vb.),

- enfeksiyon veya diğer hastalıklar nedeniyle immünosupresyon (HIV enfeksiyonu - AIDS, multipl miyelom vb.),

- radyoterapi,

- böbrek yetmezliği (GFR $\leq 30 \mathrm{ml} /$ dak, diyaliz gereksinimi),

- karaciğer yetmezliği (siroz, vb.),

- diabetes mellitus (özellikle kontrolsüz olgular),

- kalp yetmezliği (ejeksiyon fraksiyonu $\leq \% 40$ ),

- solunum yetersizliği (oda havasında arteriyel $\mathrm{O}_{2}$ $<\% 60$ ),

- kronik malnütrisyon (albümin $\leq 3 \mathrm{gr} / \mathrm{dl}$ ),

- metastatik tümörler (immün orijinli olmayan),

- kronik idrar sondası kullanımıve

- sigara kullanımı (>1 paket/gün) ve alkol bağımlılı̆̆ıdır.

Lokal ekstremite evresi (yara) faktörleri;

- aktif enfeksiyon varlığı (>3-4 aydır),

- çoğul insizyon (deri köprüleri oluşturulması),

- önceki travmada yumuşak doku kaybı,

- subkutan abse $\left(>8 \mathrm{~cm}^{2}\right)$,

- sinoviyal kutanöz fistül,

- eklemde geçirilmiş periartiküler kırık/travma (özellikle Crush yaralanma),

- yara bölgesine lokal radyoterapi yapılma anamnezi,

- ekstremitede vasküler yetmezlik (nabızların alınmaması, kronik venöz staz, anlamlı kalsifik arteriyel hastalık) ve

- refleks sempatetik distrofidir.

Genel kanı; geriatrik yaş, geçirilmiş artroplasti ve geçirilmiş total protez enfeksiyonunun, predispozisyon yaratan çok önemli faktörler olduğudur. Yapılan geriye dönük olgu kontrollü bir çalışmada, risk faktörleri araştırılmış; kalça ve diz eklem protez enfeksiyonu olan hastalar olgu grubuna, protez takılmayan veya protez enfeksiyonu gelişmeyen hastalar kontrol grubuna alınmış; multipl lojistik regresyon analiz modeli, cerrahi yara enfeksiyonu varlığı (eklemi tutmamış), NNIS sistem cerrahi hasta risk indeks skorunun 1 veya 2 olması, malignite varlığı ve geçirilmiş eklem 
artroplasti anamnezinin varlığının, total protez enfeksiyon riskini arttırdığını göstermiştir. Tutulan eklemde daha önce cerrahi operasyon yapılması, yerleştirilen protezin yeri ve tasarımı (diz artroplastisi ile enfeksiyon insidansı kalça artroplastisinden daha yüksek insidansa sahiptir), operasyondan sonraki dönemde bölgesel hematom veya yüzeysel yara enfeksiyonu gelişimi bulunmaktadır. İsveç'te, 12.118 primer diz artroplastisi yapılan bir grupta, geniş protez, cerrahi sonrası yara iyileşme komplikasyonları, romatoid artrit, geçirilmiş derin bir enfeksiyon ve deri enfeksiyonları, risk faktörleri olarak bildirilmiştir. Yapılan çalışmalarda, hastaların yaklaşık \%20'sinin romatoid artritli olduğu bildirilmektedir. Bunların \%40'tan fazlası kortikosteroid tedavisi görmektedir. Romatoid artritli hastalar, hem hastalıkları hem de çoğu kez kortikosteroid kullanımı nedeniyle, istatistik anlamlılık olmasa da, artmış enfeksiyon riski altındadır. İsveç diz artroplasti - romatoid artrit kayıt sisteminde, protezli hastalarda enfeksiyon nedeniyle revizyon riski, romatoid artritli hastalarda diğer osteoartritik gruplara göre 1,8 kat fazladır. Kortikosteroid tedavisi gören diğer hastalar (son bir yıl içinde $\geq 1$ hafta); inflamatuvar artritler, kronik deri hastalıkları, kronik karaciğer hastalıkları, astım, myasthenia gravis, böbrek transplantasyonu ve diğer maligniteler, artmış enfeksiyon riski altındadır. Total eklem artroplastisinden önceki beş yıl içinde tanı konulan prostat kanseri, gastrointestinal sistem kanserleri, meme kanseri, jinekolojik kanserler, hipernefrom, osteosarkom, diğer kemik tümörleri, mesane kanseri, skuamöz hücreli kanser, metastatik orijini bulunmayan tümörler, Sezary sendromu, lenfoproliferatif hastalıklar ve primer eklem tümörleri de riski arttırabilir. Radyoterapi, yara iyileşmesini geciktiren, dolayısıyla enfeksiyona zemin hazırlayan, enfeksiyon riskini arttıran bir faktördür. Cerrahi öncesi beslenme bozukluğunun ve düşük albümin seviyelerinin, enfeksiyon sıklığının artışıyla birlikte olduğu ve hastanede yatış süresini uzattığı bildirilmiştir. Obezite, vücut ağırlığının idealden $>\% 20$ oluşu, hasta özellikle aynı zamanda diyabetik ise, genel olarak enfeksiyonun daha hızlı ilerlemesi, komşu yapılara yayılması ve yaşamı tehdit edecek ağırlıkta seyretmesine neden olur. Cerrahi öncesi lenfosit sayısı $<1500 / \mathrm{mm}^{3}$ olan hastalarda enfeksiyon riskinin daha fazla olduğu da bilinmektedir. HIV enfeksiyonu ve düşük CD4 lenfosit sayısının, cerrahi yara enfeksiyonu riskini arttırıp arttırmadığı tartışmalıdır; bazı yayınlar, bunların riski arttırdığını bildirmektedir. Yapılan ileriye dönük bir çalışmada ise, ortopedik cerrahi yara enfeksiyonlarının CD4 lenfosit sayısına bağlı olmadığı, kontrollerle aynı oranlarda olduğu bildirilmiştir. Yaraya bağlı komplikasyonların sıklığının, cerrahi öncesi 6-8 hafta sigara kullanımının kesilmesi durumunda anlamlı oranda azaldığı bildirilmektedir. Bu nedenle, protez takılacak hastalara ameliyat öncesi en azından 6-8 hafta sigara içmemeleri tavsiye edilmelidir. Cerrahi öncesi pyüri, bakteriüri, yineleyen üriner sistem enfeksiyonları ve hemofili de risk faktörleri olarak bildirilmiştir. Yirmi dört saatlik zaman dilimi içinde yapılan kan tranfüzyonlarının, cerrahi işlem sırasında enfeksiyon riskini arttırdığı bildirilmiştir. Bu nedenle, gerekli transfüzyonların mümkün olduğunca bu zaman dilimi içinde yapılmamasına çalışılmalıdır. Öğleden sonra $(>12.00)$ yapılan ameliyatlarda enfeksiyon riski artmaktadır. Cerrahi öncesi protez takılacak ekleminde veya vücudunun diğer bir bölgesinde enfeksiyon olan hastalar, mutlaka enfeksiyon hastalıkları uzmanıyla konsülte edilerek enfeksiyon kontrol altına alınmalı ve eklem protezi daha sonra takılmalıdır.

Enfeksiyonun başlaması, eklemin bakteriyel kontaminasyonu, ya protez yerleştirilirken ya da yerleştirildikten sonra olur. Aseptik yöntemlere karşın, operasyon sırasında, hava yoluyla, genellikle ameliyat odasındaki kişilerin deskuame olan deri parçalarının yayılmasıyla, kontaminasyon olabilir; diğer yandan, hastanın kendi derisinden veya cerrahın elinden de, delinmiş eldivenden geçerek bulaşma olabilir. Özel hava temizleme sistemleri, ameliyathanelerde gelişen enfeksiyon riskini azaltabilmektedir. Cerrahiden sonra başlayan derin enfeksiyonun nedeni, uzak bölgelerden bakterilerin hematojen olarak yayılmasıdır. Bunların çoğunun, deri lezyonlarından, solunum sisteminden, idrar yollarından ve ağız boşluğundan köken aldığına inanılmaktadır.

Bir çok seride, ameliyattan sonraki ilk iki yıl içinde ortaya çıkan protez enfeksiyonlarının \%80-90'ının operasyon odasından kaynaklandığı, hematojen olarak gelişenlerin de kalan kısmı oluşturduğu gösterilmiştir. ${ }^{[25]}$

Protezi yerleştirme işleminden sonraki saatlerde, protezin yüzeyi, bazıları hem hücrelerin hem de bakterilerin yapışmasını kolaylaştıran, reseptör görevi yapan glikoproteinlerden oluşan bir tabaka ile kaplanır. Yapışma meydana geldikten sonra, birçok bakteri sli$m e$, yani glikokaliks üretir. Bu madde, yapışmayı geri dönüşümsüz hale getirir, besinlerin en iyi yoğunlukta tutulmasını sağlar ve hem lökositler tarafından fagositoza hem de antibiyotiklere karşı korunma sağlar. Bakterilerin doku içine ilk girişlerinden sonra, konak savunmaları 2-5 saat içinde enfeksiyonu bölgesel olarak sınırlar ve komşu dokulara yayılmasını önler. Bu kararlı dönemde, antibiyotikler toplam bakteri sayısının azaltılmasında ve dengelerin konak savunmalarının lehine çevrilmesinde başarılı olur; ancak, bu dönemden sonraki etkileri çok kısıtlıdır. 


\section{PERIPROSTETIK PROTEZ ENFEKSIYONLARINDA ANTIBIYYOTERAPI}

Periprostetik protez enfeksiyonları, tedavisi en güç olan enfeksiyonların ilk sıralarında yer almaktadır; çünkü, antibiyoterapide farmakokinetik sorunlar vardır, antibiyotikler genellikle kemikte yoğunlaşmaz ve kemik korteksinde antibiyotik düzeyi, serum konsantrasyonunun \%5'inden daha az olabilir. Bu yüzden, antibiyotiğin hem serum düzeyi yüksek olmalı hem de uzun süre bu düzeyde kalmalıdır. Periprostetik protez enfeksiyonlarında sadece antibiyoterapi tedavide yeterli değildir, hemen her olguda cerrahi girişim şarttır.

Periprostetik protez enfeksiyonlarının tedavisi genellikle uzun süreli ( $>2$ ay) antibiyotik tedavisi gerektirdiğinden, seçilecek antibiyotiğin toksik, istenmeyen etkileri olmamalı veya minimal olmalıdır.

Tedaviden önce, mutlaka hastadaki enfeksiyonun etkeni belirlenmeye çalışılmalıdır. Hasta septik tabloda değilse, Gram preparatı ve kültür sonuçları çıkana kadar tedaviye başlanmamalıdır. Yüzeyel sürüntü ve fistül ağzından alınan cerahat kültürlerinin önemi yoktur; sıklıkla kolonize bakteriler üretilir. Buna karşın, doku kültürleri (kemik-derin yumuşak doku) çok yararlıdır.

Antibiyotiklerin kemik penetrasyonları çok iyi değildir. Bu nedenle, başlangıç tedavisinde antibiyotikler parenteral uygulanmalıdır. Daha sonraki aşamada, kemik dokusuna iyi geçen antibiyotik söz konusu ise, oral idame tedavisine geçilebilir. Uygun başlanan bir antibiyoterapi, kemik destrüksiyonu olmadan önce, iyi klinik sonuç alınmasına yardımcı olur. Tüm olgular cerrahi debridman açısından değerlendirilmeli ve gerektiğinde, debridman vakit geçirilmeden uygulanmalıdır.

Periprostetik protez enfeksiyonlarında da antibiyotik tedavisi güçtür; öncelikle değerlendirme yapılmalıdır. Antibiyotik monoterapisi, sadece cerrahi girişim yapılamayan olgularda düşünülmelidir.

Tedavi, istisnai olgular dışında, mutlaka antibiyogram eşliğinde, rasyonel olarak yapılmalıdır.

\section{CERRAHI ÖNCESI ANTIBIYOTIK PROFILAKSISI NASIL YAPILMALIDIR?}

Bakteriyel kontaminasyon, her cerrahi insizyonun bir komponentidir. Kontaminasyondan sonra enfeksiyon gelişimi, hastanın immün sistemi ile kontaminan bakterilerin sayı ve virulansı arasındaki karşıııkı etkileşime bağlıdır. Protez cerrahisinde, antibiyotik profilaksisi ile bakteri yükü azaltılarak cerrahi yara/alan enfeksiyonu gelişim riski azaltılabilir. ${ }^{[26]} 1957$ yılından beri yapılan çalışmalar ortopedik cerrahide antibiyotik profilaksisinin etkinliğini gösterdiğinden, antibiyotik profilaksisi standart hale gelmiştir.[26]

Antibiyotik profilaksisi, enfeksiyon veya kontaminasyon olmadan, dokular bakterilerle karşılaşmadan önce, gelişmesi yüksek olası enfeksiyonların önlenmesi için yapılan antibiyotik uygulamalarıdır. Cerrahi insizyon sırasında girişim bölgesinde yeterli antibiyotik konsantrasyonu sağlanması, profilaksinin ön koşuludur.

Protez girişimlerde, özellikle yabancı cisim takılan ve iki saatten uzun süren antibiyotik profilaksisinin, cerrahi sonrası enfeksiyon riskini azalttığı genel kabul görmektedir. Amaç, ameliyat sırasında ve hemen sonrasında ameliyat bölgesi dokularında yeterli antibiyotik düzeyi sağlamak, bakteriyel florayı azaltmak ve olabilecek kontaminasyonu konağın karşı koyabileceği düzeye indirgemektir.

Cerrahi sonrası protez enfeksiyonlarında en sık etkenler Staphylococus aureus ve koagülaz-negatif stafilokoklar olup, kaynak hastanın deri florasıdır. Tüm protez girişimlerinde cerrahi yara enfeksiyonu oluşabilir. Protez girişimlerinde kullanılacak antibiyotikler stafilokoklara mutlaka etkili olmalıdır.

Profilakside seçkin ajan sefazolindir; metisiline duyarlı stafilokoklara etkilidir. İstenmeyen etkiler düşük orandadır ve anafilaktik reaksiyon çok seyrektir. Penisiline bağlı deri döküntüsü olan hastalarda da kullanılabilir. Sefazolin, indüksiyonla birlikte 1-2 gr iv uygulanmalı, girişim dört saati aşarsa, girişim sırasında ikinci doz uygulanmalıdır. Profilaksi süresi 24 saati geçmemelidir. Alerji nedeniyle sefazolin kullanılamadığı takdirde, vankomisin veya teikoplanin kullanılmalıdır.

Metisiline dirençli stafilokok oranı yüksek olan kliniklerdeki yabancı cisim (eklem protezi, vb.) takılan girişimlerde, sefazolin yerine vankomisin veya teikoplanin kullanılması tercih edilmelidir. Girişim başlamadan önce, 1 gr vankomisin veya $400 \mathrm{mg}$ teikoplanin infüzyonu bitmiş olmalıdır.

Yapılan çalışmalar, artroplasti operasyonlarında da antibiyotik profilaksisinin gerekliliğini ortaya koymuştur. Profilaktik antibiyotik uygulaması, mutlaka cerrahi öncesi başlatılmalıdır. İdeal zaman, insizyondan 30-60 dakika öncedir. Zamanlama, antibiyotik profilaksisinin etkinliği açısından en önemli faktörlerin başında gelmektedir. Uzamış operasyonlarda (kullanılan antibiyotiklerin yarı ömrünün 1-2 katı sürelerle), antibiyotik uygulamaları tekrarlanmalıdır. Profilaktif antibiyotik uygulama süresinin limitli olmasının gerekçeleri vardır: antibiyotik istenmeyen etki oranının azaltılması, antibiyotiklere direnç gelişiminin azaltılması ve maliyetin düşük tutulması. 


\section{CERRAHI SONRASI PROFILAKSI}

Protez girişimlerinde enfeksiyon önemli bir komplikasyondur. Evre I'de (ilk üç ay) enfeksiyon oranı \%1'den az iken, daha sonraki aylar ve yıllar içinde oran artmakta ve \%1-4'e yükselmektedir. Evre l'de en sık direkt kontaminasyon ve bu da komşu yumuşak doku enfeksiyonunun yayılması ile ortaya çıkarken; daha sonra hematojen yolla da ortaya çıkar. Total protez uygulanacak hastanın cerrahi öncesi genel bir değerlendirilmesi yapılmalıdır. Pyüri varsa idrar kültürü yapılmalı ve üreme varsa tedavi edilmelidir. Protez takılacak hastalarda burun sürüntü kültürü yapılmalı ve MRSA taşıyıcılığı varsa cerrahi öncesi ortadan kaldırılmalıdır. Hastaya diş kontrolü yaptırılmalı, lokal enfeksiyon saptanırsa, girişim öncesi tedavi edilmelidir. Hastanın muayenesinde deri - yumuşak doku enfeksiyonu saptanırsa, mutlaka tedavi edilmelidir. Diyabetli hastalarda kan glikozu mutlaka regüle edilmelidir. Girişim öncesi lenfosit sayısı $1500 / \mathrm{mm}^{3}$ veya daha yüksek, albümin düzeyi en az 3,5 gr/dl olmalıdır; böylece yara enfeksiyon riski daha düşük olacaktır.

Protez takılacak hastalar, ameliyat günü veya bir gün önce hastaneye yatırılmalıdır. Cerrahi öncesi uzun süreli yatış, enfeksiyon sıklığını arttıran çok önemli bir faktördür.

Protez girişimleri uygulanacak ameliyathaneler, uluslararası kabul gören standartları içermelidir. Ameliyathane disiplininin özellikle çok önemli olduğu, mutlaka akılda tutulmalıdır.

Total protez takılacak girişimlerde, antibiyotik profilaksisi uygulanmalıdır.

Cerrahi sonrası dönemde, hasta mümkün olduğunca erken taburcu edilmeli, fizyoterapi ve rehabilitasyon mümkün olduğunca başka yerde yapılmalıdır.

Hematojen enfeksiyon riskinin en yüksek olduğu zaman dilimi, cerrahi sonrası ilk iki yıldır. Daha sonraki zaman diliminde hematojen enfeksiyonları önlemek için, bakteriyemiye yol açabilecek girişimlerde antibiyotik profilaksisi konusunda rehberler vardır. Özellikle diş girişimlerinde ve ürolojik girişimlerde, hastalara antibiyotik profilaksisi öneren hekimler/diş hekimleri vardır.

Tüm dental ve ürolojik girişimlerde antibiyotik profilaksisine gerek yoktur. Profilaksi gereken durumlar;

- bakteriyemi riski yüksek olan ürolojik girişimler (herhangi bir taş girişimi (ESWL dahil)

- üriner sisteme transmural insizyon yapılan tüm girişimler (eksizyonlu basit ligasyon veya perkütan drenaj girişimi),

- üst üriner sisteme herhangi bir endoskopik girişim (üreter ve böbrek),
- kolon segmentlerini de içeren girişimler,

- transrektal prostat biyopsisi,

- yüksek bakteriyel kolonizasyon riski taşıyan, üriner sisteme girilen her türlü girişim (transüretral kateterizasyon dışında) ve

- dental girişimlerdir (tüm diş çekimleri, tüm periodontal girişimler, dental implant girişimleri, kanal tedavilerinin bir kısmı, ortodontik bantların ilk takılması, spesifiye edilmiş lokal anestetik injeksiyonları, kanama olabilecek durumlarda düzenli diş temizliği).

Gastrointestinal girişimlerde bakteriyemi sıklığı (\%0-8) ve yoğunluğu düşüktür; enfeksiyöz komplikasyonlara yol açmaz. Fleksibl sigmoidoskopide bakteriyemi sıklığı \%0-1, kolonoskopide \%0-25'tir (ortalama $\% 4,4)$. Şimdiye kadar sadece, inoperabl özofagus kanseri nedeniyle yapılan lazer tedavisi sonrası bir hastada total protez enfeksiyonu bildirilmiştir. Endoskopik girişimler sonrası total protez enfeksiyonu görülme sıklığı çok seyrek olduğu için, gastroenterolojik endoskopik girişimlerde rutin antibiyotik profilaksisine gerek yoktur.

Bazı özel durumlarda ve bazı özel girişimlerde, profilaktik antibiyotik kullanımına hasta bazında karar verilmelidir.

Total protezi olan hastalarda en sık gelişebilecek enfeksiyonlardan olan deri - yumuşak doku (dekubitüs ülseri dahil), üriner sistem vb. (özellikle sonda) enfeksiyonlarının varlığında; özellikle bakteriyemiye yol açabilecek olanların çok erkenden tedavisine başlanması da, geç total protez enfeksiyonlarının önlenmesinde önemlidir.

\section{KAYNAKLAR}

1. Anguita-Alonso $P$, Hanssen $A D$, Patel R. Prosthetic joint infection. Expert Rev Anti Infect Ther 2005;3(5):797-804.

2. Bernard L, Hoffmeyer $P$, Assal $M$, Vaudaux $P$, Schrenzel $J$, Lew D. Trends in the treatment of orthopedic prosthetic infections. J Antimicrob Chemother 2004;53(2):127-9.

3. Getzlaf MA, Lewallen EA, Kremers HM, Jones DL, Bonin CA, Dudakovic A, Thaler R, Cohen RC, Lewallen DG, van Wijnen AJ. Multi-disciplinary antimicrobial strategies for improving orthopaedic implants to prevent prosthetic joint infections in hip and knee. J Orthop Res 2016;34(2):177-86. Crossref

4. Lidgren L, Knutson K, Stefánsdóttir A. Infection and arthritis. Infection of prosthetic joints. Best Pract Res Clin Rheumatol 2003;17(2):209-18.

5. Osmon DR, Berbari EF, Berendt AR, Lew D, Zimmerli W, Steckelberg JM, Rao N, Hanssen A, Wilson WR; Infectious Diseases Society of America. Diagnosis and management of prosthetic joint infection: clinical practice guidelines by the Infectious Diseases Society of America. Clin Infect Dis 2013;56(1):e1-e25. Crossref 
6. Sia IG, Berbari EF, Karchmer AW. Prosthetic joint infections. Infect Dis Clin North Am 2005;19(4):885-914.

7. Sperling JW, Kozak TK, Hanssen AD, Cofield RH. Infection after shoulder arthroplasty. Clin Orthop Relat Res 2001;(382):206-16.

8. Trampuz A, Zimmerli W. Prosthetic joint infections: update in diagnosis and treatment. Swiss Med Wkly 2005;135(17-18):243-51.

9. Widmer AF. New developments in diagnosis and treatment of infection in orthopedic implants. Clin Infect Dis 2001;33 Suppl 2:S94-106.

10. Zimmerli W, Trampuz A, Ochsner PE. Prosthetic-joint infections. N Engl J Med 2004;351(16):1645-54.

11. Laffer RR, Graber P, Ochsner PE, Zimmerli W. Outcome of prosthetic knee-associated infection: evaluation of 40 consecutive episodes at a single centre. Clin Microbiol Infect 2006;12(5):433-9.

12. Brown WJ. Microbiology of the infected total joint arthroplasty. Semin Arthroplasty 1994;5(3):107-13.

13. Atkins BL, Athanasou N, Deeks JJ, Crook DW, Simpson H, Peto TE, McLardy-Smith P, Berendt AR. Prospective evaluation of criteria for microbiological diagnosis of prosthetic-joint infection at revision arthroplasty. The OSIRIS Collaborative Study Group. J Clin Microbiol 1998;36(10):2932-9.

14. Peel TN, Dylla BL, Hughes JG, Lynch DT, GreenwoodQuaintance KE, Cheng AC, Mandrekar JN, Patel R. Improved Diagnosis of Prosthetic Joint Infection by Culturing Periprosthetic Tissue Specimens in Blood Culture Bottles. MBio 2016;7(1):pii:e01776-15. Crossref

15. Trampuz A, SteckelbergJM, Osmon DR, Cockerill FR, Hanssen $A D$, Patel R. Advances in the laboratory diagnosis of prosthetic joint infection. Rev Med Microbiol 2003;14(1):1-14.

16. Özsüt $\mathrm{H}$, Tözün $\mathrm{R}$, Çağatay $\mathrm{A}$, Eraksoy $\mathrm{H}$. Kronik osteomyelit ve total protez infeksiyonlarında yüzeyel sürüntü kültürleriyle, derin doku veya aspirat materyallerinin mikrobiyolojik sonuçlarının karşılaştırılması. Klimik Derg 2007;20(3):71-6.

17. Bémer $P$, Léger J, Tandé $D$, Plouzeau $C$, Valentin AS, JolivetGougeon A, Lemarié C, Kempf M, Héry-Arnaud G, Bret L, Juvin ME, Giraudeau B, Corvec S, Burucoa C; Centre de Référence des Infections Ostéo-articulaires du Grand Ouest (CRIOGO) Study Team. How Many Samples and How Many Culture Media To Diagnose a Prosthetic Joint Infection: a Clinical and Microbiological Prospective Multicenter Study. J Clin Microbiol 2016;54(2):385-91. Crossref
18. Matsen Ko L, Parvizi J. Diagnosis of Periprosthetic Infection: Novel Developments. Orthop Clin North Am 2016;47(1):19. Crossref

19. Melendez DP, Greenwood-Quaintance KE, Berbari EF, Osmon DR, Mandrekar JN, Hanssen AD, Patel R. Evaluation of a Genus- and Group-Specific Rapid PCR Assay Panel on Synovial Fluid for Diagnosis of Prosthetic Knee Infection. J Clin Microbiol 2016;54(1):120-6. Crossref

20. Sousa RJ, Barreira PM, Leite PT, Santos AC, Ramos MH, Oliveira AF. Preoperative Staphylococcus aureus Screening/ Decolonization Protocol Before Total Joint ArthroplastyResults of a Small Prospective Randomized Trial. J Arthroplasty 2016;31(1):234-9. Crossref

21. Davey PG, Rowley DR, Phillips GA. Teicoplanin -home therapy for prosthetic joint infections. Eur J Surg Suppl 1992;(567):23-5.

22. Eisen DP, Denholm JS. Recommendations for rifampicin therapy of staphylococcal infection in Infectious Diseases Society of America prosthetic Joint Infection Guidelines are not supported by available literature. Clin Infect Dis 2013;57(1):159-60. Crossref

23. Rao N, Soxman GL. Prosthetic joint infections in elderly. Operative Techniques in Orthopedics 2002;12(2):131-8. Crossref

24. Berbari EF, Hanssen AD, Duffy MC, Steckelberg JM, Ilstrup DM, Harmsen WS, Osmon DR. Risk factors for prosthetic joint infection: case-control study. Clin Infect Dis 1998;27(5):1247-54.

25. Tande AJ, Palraj BR, Osmon DR, Berbari EF, Baddour LM, Lohse CM, Steckelberg JM, Wilson WR, Sohail MR. Clinical Presentation, Risk Factors, and Outcomes of Hematogenous Prosthetic Joint Infection in Patients with Staphylococcus aureus Bacteremia. Am J Med 2016;129(2):221.e11-20. Crossref

26. Bedenčič K, Kavčič M, Faganeli N, Mihalič R, Mavčič $B$, Dolenc J, Bajc Z, Trebše R. Does Preoperative Antimicrobial Prophylaxis Influence the Diagnostic Potential of Periprosthetic Tissues in Hip or Knee Infections? Clin Orthop Relat Res 2016;474(1):258-64. Crossref 